\title{
DEVELOPING TEACHERS' GUIDE TO USE FACEBOOK GROUP IN A BLENDED WRITING COURSE (A Research and Development in IAIN Surakarta)
}

\author{
Roko Patria Jati
}

Graduate Program of English Education of FKIP UNS

bee.ascholar@gmail.com

\begin{abstract}
This study aimed to investigatethe existence and the quality of any teachers' guides used for Writing Course in IAIN Surakarta as well as the level of need and related criteria for development. Besides, the developmental steps in developing new teachers' guide (to use Facebook Group in a blended Writing Course) were also investigated. This research-based development $(R \& D)$ was conducted in IAIN Surakarta by involving ten teachers and 115 students. The findings of this study were obtained through some qualitative techniques, such as interview, observation, document analysis, and focus group. As the results, it was found that among ten tertiary teachers, only one of them using teachers' guide or book to teach in the Writing Course. However, nine of them stated their need on the proposed product and one stated his uncertainty. Further, the related supportswere also shown by majority of the students involved. Afterward, the draft was developed by considering some suggested criteria of development. After being validated by the related expert, the product was then field tested involvingthree teachers and 48 students. Through the tryouts conducted, the level of feasibility on the procedure had improved significantly to 97\%, 94\% and $92 \%$ in the last three tryoutsdelivered by three different teachers. The tryout was terminated as suggested by the field expert and after the supervisor stated the credible justification had been reached. Finally, after being revised as recommended, the teachers' guide was ready-to-use in a blended writing course context.
\end{abstract}

Keywords: Teachers' guide, Facebook Group, blended Writing Course

\section{INTRODUCTION}

Technology is a main cause of rapid changes in globalization era, including in education.

The new educational methods which considerably meet the challenge of rapidly growing technology are usually related to e-learning, also termed as online learning. Tri, Made, and Boedhi, 2007: 101) mention that e-learning or electronic learning is a concept of ICT-based learning especially in the usage of internet-based media. However, regardless many promising features of online instruction, certain pitfalls of online instruction have been identified regarding 
its limited capability to engage learners in learning events unless the learners were self-motivated and active learners (Daniels and Moore, 2000).

Being displeased with e-learning, blended learning has recently received increased usage among academic institutions and private companies that have many opportunities associated with time and place (Picciano, 2006). The major thrust of blended instruction is to overcome the shortcomings of online instruction and utilize various instructional sequencing and delivery strategies to enhance learner satisfaction while also achieving increased learning outcomes. In this case, face-to-face learning should be synchronized with e-leaning as the answer to nowadays technological challenge.

In Indonesia, there are several higher education institutions working on this blended learning project. It was started when Indonesia Ministrial of Education put effort to develop distance learning in higher education through a strategic plan issued in 2005. There are several higher education institutions which were appointed to implement the piloting projects such as ITB, ITS, UGM, IPB, UI, UNRI, UNDANA, UNHAS, PENS, dan POLMAL. Dissemination of this project is addressed to UNLAM, UM, UNY, UNP, UNHALU, UNCEN and other institutions (Renstra Depdiknas, 2005: 98).

Blended learning is regarded by many higher education institutions as a solution for responding the new intervention and role of technology. For example, UniversitasSebelasMaret (UNS) has prepared a long term program for the period of 2009-2029 which includes management and staff preparation for ICT implementation. The UNS Rector states that blended learning is applied in his campus by providing online course materials for structured task-based learning as well as self learning. For the progress, there are around a third of thousands of course material of 374 courses are provided online (Kontak UNS, $6^{\text {th }}$ February 2013: 4).

According to Graham, 2006: 11), blended learning at the institutional and program levels is often left to the maturity of the learner, while designers and instructors are more likely to take a role in prescribing the blend at the course and activity levels. In addition, Huang, Ma and Zhang, 2008: 7-9) state that development of course materialsin blended learning design model is actually only one of two blended learning's feet. Another foot which is even more important is 
the design of a unit or an activity. Therefore, besides designing the online materials, the teachers should more importantly get familiar with any online tools or media. This will help them in the development of blended learning process at course level as well as activity model.

Designing a unit of blended learning process or only a single activity of blended learning is not something restricted in Indonesia. Instead, the regulation of a credit unit combining faceto-face meeting, structured task, and self learning (PP No 17 Tahun 2010 article 87 and Kepmendiknas No 232/U/2000 article 1) is considered by some experts as a blended learning. On the other hand, other experts still require the element of online learning to refer it as a blended learning. Somehow, the related regulations above have proved that the existence of SKS is aimed at supporting a blended learning model, especially at the course level by teachers. However, many of them do not even really care with the significance of such regulation.

A new trend of combining face-to-face and online learning or called as blended learning is actually applicable for any courses. Viewed from the website original idea and its development, one of the closest courses is a Writing Course. Writing activities in any Writing Courses can be facilitated by any online tools or media. The existing media have made writing processes become much simpler. Writers or learners can just write something and share it online. Afterward, they can easily get some comments for their writing and make revision and edit based on those comments. The challenge and opportunity then is for any Writing Courseteachers to develop those activities and arrange them in a unit of a course.

However, the state-of-the-art condition of writing course in IAIN Surakarta was not yet upgraded to meet the challenge of blended learning as the up-to-date context. In fact, the related parties in IAIN Surakarta actually had their own potentials to do so.From the preliminary observation of this research, I found that the teachers were already familiar with social media and Facebook has become the most popular one. There were about seven Facebook Groups found in association to IAIN Surakarta. However, the contents posted there were not yet purposed for facilitating online learning activities. They were mainly posted for educational information and a little bit of course materials. Those materials were not followed with related online activities. No specific activities were determined and developed to really make use of Facebook Group as a tool for online learning activities. To conclude, there was obviously a gap between the existing 
condition and the recent context which must be connected in the development of any educational products including teachers' guides.

\section{Objectives}

This research-based development was conducted for the purposes of investigating the existence as well as the quality of any teachers' guides used for Writing Course in IAIN Surakarta. Besides, the level of need and the criteria for the proposed product were also investigated from the Writing Course teachers and their students. In this case, the proposed product was a new teachers' guide to use Facebook Group in a blended Writing Course. Afterward, this research was continued with the next purpose of investigating several developmental steps implemented to develop the proposed product in IAIN Surakarta.

\section{Teachers' guide}

The term 'teachers' guide' and 'teachers' book' are interchangeably used by Cunningsworth and Kusel, 1991 and Cunningsworth, 1995) to refer to the same educational product. According to Cunningsworth, 1995: 112), a good teachers' book is guidelines on how to make the best use of the course, detailed plans for teaching each unit and keys to the exercises, besides a number of possible roles or functions that teachers' book can fulfill. From the explanation above, it can be concluded that teachers' guide (TG) is a guideline intended to guide certain teachers in teaching or delivering certain course. TGs usually take a role as a companion of related materials (textbook, etc); however, recent development of technology has forced TG to be guidance for using media or technology.

\section{Product and Process of Writing}

Traditionally, a distinction has been drawn between the learning activities which focus on products and the activities which focus on process in curriculum practice, including in teaching or learning writing. In the product oriented approach, teachers pay attention to the learners' final product of writing with a list of criteria including content, organization, vocabulary use, grammatical use, and mechanical considerations such as spelling and punctuation (Brown, 2001: 335). Process approach, on the other hand, focuses more on the various classroom activities which are believed to promote the development of skilled language use (Nunan, 1991). The new emphasis on the process, however, must be seen in the prospective of a balance between process 
and product. "The product is, after all, the ultimate goal; it is the reason that we go through the process of prewriting, drafting, revising, and editing" (Brown, 2001: 337). Therefore, in a blended Writing Course, the processes need to be designed on which of them fit in the typical face-to-face meeting and which fit in the typical online activity.

\section{Blended learning}

Blended learning is defined by many as a combination of two pedagogical approaches, classroom or face-to-face and e-learning (Garrison and Vaughan, 2008; Arbaugh, Desai, Rau and Sridhar, 2010; Graham, 2006). However, some other experts are taking a broader view in that it is a mix of delivery methods and goes beyond e-learning and classrooms to accommodate the various learning needs of a diverse audience in a variety of subjects (King and Mc. Sporran, 2005).

Graham (2006: 4) explores three most commonly mentioned definitions as documented by Graham, Allen, and Ure, they are: (1) combining instructional modalities (or delivery media); (2) combining instructional methods; and (3) combining online and face-to-face instruction. The first two positions reflect the debate on the influences of media versus method on learning. Both of these positions suffer from the problem that they define BL so broadly that they encompass actually all learning systems. One would be hard-pressed to find any learning system that did not involve multiple instructional methods and multiple delivery media. Thus defining blended learning in either of these two ways waters down the definition and does not get the essence of what blended learning is and why it is exciting to so many people. In other hand, the third position more accurately reflects the historical emergence of blended learning systems.

In defining blended learning, Graham (2006: 5) states that blended learning systems combine face-to-face instruction with computer-mediated instruction. It reflects the idea that blended learning is the combination of instruction from two historically separate models of teaching and learning: traditional face-to-face learning systems and distributed learning systems. It also emphasizes the central role of computer-based technologies in blended learning. Based on several definitions above, blended learning can be defined as a combination between face-to-face learning and e-learning in order to blend the positive things of both instructional models. 
According to Graham (2006: 10-12), blended learning occurs at one of the following 4 (four) levels: (1) activity level; (2) course level, (3) program level, or (4) institutional level. Across all four levels, the nature of the blends is determined by the learner or the designer or instructor. Blending at the institutional and program levels is often left to the discretion of the learner, while designers and instructors are more likely to take a role in prescribing the blend at the course and activity levels.

\section{Facebook Group}

Facebook Group is one of Facebook's popular features to privately connect with specific sets of people, like family, teammates or coworkers. Through this private space, members can share updates, photos or documents and message other group members. Creator or admin can also select one of three privacy options for the created group (www.facebook.com/help). Founded at February 4, 2004 by Mark Zuckerberg, Facebook as a social networking site has quickly become one of the most used and visited platforms to communicate and connect. The Education Foundation (2013: 2) notes that there were 1.1 billion people using Facebook around the world by May 2013.

In realizing their mission, Facebook has been working with schools, colleges, universities and other related parties to better understand how the service can be used in and out of classrooms as a tool for learning and harness its potential to improve learning outcomes for young people. Meanwhile, the use of Web 2.0 tools (including Facebook) is becoming more widespread and has been much examined in the language learning classroom, e.g. PromnitzHayashi (2011); Greenhow, Robelia, and Hughes (2009); Fontana (2009). As a result of their project, The Education Foundation (2013: 4) sees Facebook as a vital tool for teaching and learning in the $21^{\text {st }}$ century and for making education more social. It is an essential 'toolbox for educators' in schools, colleges, universities and other learning settings to open up, inspire and catalyze young people's learning.

\section{Rationale}

Many teachers have already practiced the product and process-oriented method of writing in balance. However, only few of them consider ICT as the up-to-date global context influencing the context of teaching and learning. Some teachers seem reluctant to move from their traditional 
Writing Course to the new context of teaching and learning as the logical consequences. Not fully online, it is a blended learning aiming to blend the positive things of both face-to-face and online learning. To realize this blended learning, certain supporting online tool is required and Facebook as one of the most popular media has a great potential to be developed accordingly.

Like it or not, the change is right in front of teachers' eyes and should be responded wisely. To carefully give respond to that aggressive change, teachers had better follow the procedures of development as suggested in a research-based development. First of all, they need to investigate their students' needs, whether the students really need such change in educational context or not. When the answer is 'yes', then the teacher should collect several supporting teachers' guides to be selected. This kind of selection has reduced the potential effort of adaptation a little bit, compared to no selection at all. Furthermore, the same effort could even be reduced more if the teachers are willing to produce their own teachers' guide. By producing own teachers' guide, the learning procedure can be designed and then field-tested necessarily based on the real local context. Afterall, such development will be able to improve the quality of teaching and give the best learning experience for all the students.

\section{RESEARCH METHOD}

In this study, the sophisticated method of R\&D was used to develop a product, that is, a teachers' guide (TG) suggesting a procedure for having online learning in a blended Writing Course context. As stated by Gall, Joyce and Borg (2003: 569), this method is an industry-based development model in which the findings of the research are used to design new products and procedures, which then are systematically field-tested, evaluated, and refined until they meet specified criteria of effectiveness, quality, or similar standard. In other words, the product produced from the process of $\mathrm{R} \& \mathrm{D}$ is a validated, fine-tested and ready-to-use product.

\section{Procedure}

Simplifying ten steps of R\&D by Borg and Gall (1983: 775-776), the steps of this study consisted of: (1) studying research findings pertinent to the product to be developed; (2) developing the product based on these findings; (3) field testing it in the setting where it will be used eventually; and (4) revising to correct the deficiencies found in the field-testing stage. In 
more rigorous programs of $\mathrm{R} \& \mathrm{D}$, this cycle is repeated until the field-test data indicate that the product meets its behaviorally defined objectives.

\section{Setting}

This study was conducted at Institut Agama Islam Negeri (IAIN) Surakarta located in Kartasura, Sukoharjo, Jawa Tengah. The exploration was carried out from December 2012 until November 2013, while the developmental phase was in the odd semester of 2013/2014 academic year, starting from October 2013 until February 2014.

\section{Subjects}

The subjects of this study are varied. They are selected purposivelyto get any relevant data to develop and validate the proposed educational product. In the exploration stage, there were ten teachers and 67 students involved; while three teachers, two experts, and 48 students participated in the developmental stage.

\section{Technique of collecting data}

The findings of this study were obtained through some techniques such as interview, observation, document analysis, and questionnaire. In addition,I also applied focus group as a recently popular qualitative technique (Wilson, 1997; Morgan, 1996).

\section{Technique of validating data}

In order to cross-check and develop the data validity or trustworthiness of this research, two triangulation techniques, i.e. sources and theories, were used by the researcher. There are four techniques of triangulation as stated by Denzin in Lincoln and Guba (1985: 305), they are: (1) sources; (2) investigators; (3) methods; and (4) theories. Besides, other techniques or strategies were also applicable such as prolonged engagement, persistent observation, member check, thick description, and audit trail.

\section{Technique of analyzing data}

The process of qualitative data analysis was inductive and simultaneously conducted with the process of collecting data in the form of reflection through various techniques of reflection. Every collected data was interacted or compared with other unit of data to cross-check or develop the validity as well as to categorize the data in accordance with the formulated problems. The analysis process was conducted by applying a model by Dey (1993: 31-32) in which the data analysis is a circular process including the activities of describing, classifying, and connecting.

\section{Drafting}

The result of exploration led the researcher in arranging or preparing a draft of new product. The arrangement of product consisted of several suggested criteria for development. In 
order to make the draft theoretically credible, it was followed by some expert validation before tryout.

\section{Tryout}

In the tryout, the executing teacher delivered teaching based on the lesson plan (SAP) by making use of the developed teachers' guide as the guideline. The tryout was conducted five times by involving 3 teachers, 1 expert, and 48 students. As the nature of the suggested blended learning was just to enhance or improve the face-to-face (traditional) learning, it was not necessary to involve the whole class at once. Instead, they were grouped into several small groups to optimize the online learning itself.

\section{Monitoring and evaluation}

During the tryout implementation, the researcher intensively monitored and recorded the important or key points from the teacher's teaching, including strengths and weaknesses. Besides, monitoring and recording were also referred to the students' response, activity, and progress or achievement. After finishing a tryout, a discussion or teacher's evaluation was carried out to evaluate the whole product.

\section{Revision}

Based on the evaluation, the researcher revised the draft of the product. The same revision was also applicable for the following evaluation of tryout. This process was repeated sufficiently until the draft meets the pre-determined criteria which were supported by some judgment from the expert as well as the supervisor. After being terminated, the researcher may come to the final revision of the draft.

\section{Expert's role}

In this research and development, the experts were involved in the process of validating the draft of teachers' guide (pre-use validation) and evaluating the draft. After finishing the arrangement of the first draft, the related expert of materials development was involved in the process of pre-use validation in order to evaluate the draft just before being tested (tried-out) to the field. Besides, another expert of Writing Course was also involved to give a judgment on the feasibility of the draft after accomplishment of a tryout (in-use evaluation). The expert of 
materials development involved in pre-use validation was Ibu Dewi Rochsantiningsih from Universitas Sebelas Maret, while the expert of Writing Course was Bapak Zainal Muttaqien from IAIN Surakarta.

\section{RESULTS \\ Exploration}

\section{Existence and quality of TGs for Writing Course}

In investigating the existence of teachers' guides for Writing Course in IAIN Surakarta, I began with general questions asking about the existence of materials for language learning involving anything that can be used to facilitate the learning of a language (Tomlinson, 2012: 143). Starting from these general questions, the existence of teachers' guides could be sorted out easily.

As the result of questionnaire and interview on the general question asking about the existence of TGs or other materials, all teachers or 10 respondents mentioned that they used them to support Writing Course. Among 39 materials collected, 35 items were general materials for Writing Course, 1 item was identified as TGs or teachers' book and 3 items were other materials for teachers. The detailed distribution of materials for Writing can be seen in Figure 1.

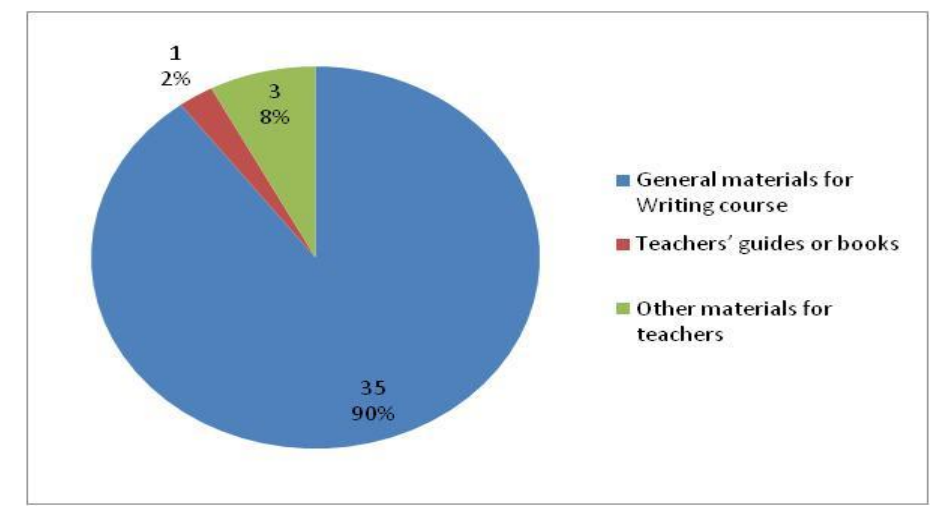

Figure 1. Language learning materials for Writing Course in IAIN Surakarta

From the categorization, there was one materialsorted out as teachers' guide or teachers' book. This could be initially indicated from the given title of the book. The book was entitled Teacher's Big Book of Graphic Organizers by Katherine S. McKnight. On the list of books title 
written on the questionnaire, there was no other TG found. In fact, some TGs were available to support the existing materials such as TG to Paragraph Writing (Zemachand Islam, 2005). The only TG used and mentioned above was employed by Teacher F especially in drafting phase. Compared to the usage of all materials, the percentage of using TG was only $2 \%$.

The Teacher's Big Book of Graphic Organizers (TBBGO) by McKnight (2010) basically describes one of teaching and learning tools namely "Graphic Organizers". The theories underlying the existence of graphic organizer usage appear in Chapter 1 titled "Why Are Graphic Organizers Such Important Tools for Teaching and Learning?" The theories are presented in a brief and concise two-page-explanation, such as the multiple intelligence of Gardner (1993: 2006), the adjustment of graphic organizers for all kinds of learners: forfor gifted children and students with special needs (Cassidy, 1991) and for adult learners (Materna, 2007), theory of mental storage by Piaget (1974) and Vygotsky (1962). Those underlying theories are considered sufficient and provide simple but basic understanding on graphic organizers utilization.

Generally, this book discusses nothing on language content, but more on language skills only. However, it is believed that the learning skills closely relates to language learning skills. The skills here include brainstorming and idea generation, vocabulary development, note taking and study skills, reading comprehension and writing as well, which later is developed in graphic organizers. The skills are not exclusively elaborated but used more to explain learning goals and indicators in every use of graphic organizer. Graphic organizer of Power Thinking (PT), as the example, provides explanation under the title stating that PT allows learners to organize ideas, terms, vocabulary, and information hierarchically into main headings and subheadings.

For the implementation of teaching and learning, TBBGO provides basic foundation in chapter 1 by subheading 'Getting Started'. The procedures proposed by the writer are only a matter of suggestions or advices for specific instructional purposes such as modeling, individual and collaborative learning, assessments, variations, and supports for students with special needs. Those general procedures are then enriched with "Tips for Classroom Implementation" which is developed for every organizer. Dealing with evaluation, TBBGO broadens teachers' knowledge that graphic organizers can be used as evaluation tools. Finally, this 226-page book is presented in concise and brief language to ease teachers' understanding. Overall, TBBGO has a good 
quality in presenting graphic organizers as general learning tools, but not specifically as language learning tools. Therefore, language teachers should give some extra effort on its adaptation or exploration for language teaching.

Besides the evaluation for the existing TG, I also found a related TG to use Facebook for teaching and learning which was relevant to be evaluated equally. The TG was titled Facebook Guide for Educators (FGE) by The Education Foundation (2013). FGE is a teachers' guide (TG) used in applying Facebook as teaching and learning tool. It consists of twenty pages which come up in two sections: 1) the first main section of nine pages and four pages of appendices; and 2) the rest seven pages of cover page, title page, contents, photos and acknowledgements. The main section elaborates the introduction to facebook, the development of the book and the development of the facebook usage. This book is developed based on some case studies of the facebook utilization at schools.

There is no specific discussion on language contents and skills in this guideline. Further, no theories or principles as well as teaching and learning evaluation is elaborated. Instead, the focus is on facebook implementation in the process of teaching and learning. This book develops the implementation separately in the main section and the appendices. In the main section, the implementation is presented on the heading entitled "Facebook as a tool for teaching and learning" and "Uses for Facebook in and around the classroom". Meanwhile, the implementation is presented on the heading entitled "Getting started with Facebook" in the appendices. Those three presentations do not have a focus on certain features such as Facebook group, Facebook page, etc. They only elaborate the facebook utilization for teaching and learning processes in broad sense. Eventhough the language presented in this guide is simple; the concern is not focused on language teaching. Thus, this guide is such a good product related to Facebook as the learning tool but it still requires more development to be used for language teaching.

\section{Need analysis of the proposed product}

As mentioned before, there was only one teachers' guide revealed (out of 39 materials) during the exploration period. In further exploration, this small number of findings remains a big gap with the teachers' real needs. Among ten teachers, nine mentioned their demands on the 
teachers' guide to help them in presenting blended learning and one teacher stated his uncertainty.

The level of needs as shown above very much depends on the teachers' perceptions on the suitability of the proposed product to the expected context. In this case, technologies and blended learning are required since they are closely related to the context of globalization era. In the interview, Teacher $\mathrm{Z}$ stated:

Saya kira, saya yakin (mahasiswa) lebih menyukai dengan teknologi ya, karena mereka kan generasi baru jadi lebih akrab dengan teknologi.

I think, I believe (that students) prefer to have technology because they are new generation so that they are more familiar with technology (TI.2).

Teacher $\mathrm{T}$ also had the same opinion about technology:

Kalau saya liat gelagatnya memang iya. Kalau tentang teknologi mahasiswa pasti sangatsangat senang sekali.

Seeing their habit, they do (like technology). If it is about technology, the students must be very pleased (TI.1).

Supporting their teachers' opinions, the finding reflects high interest of the students in employing technologies for the learning process. All the confirmed students (KA, IA, AA, and AS) mentioned that the Writing Course should integrate technology accompanied by various learning styles and practices. Further, they considered blended learning as new innovation in today modern era.

Besides clearly stated needs on the teachers' guide for implementing blended learning in Writing Course, the teachers and students also showed their needs on the utilization of Fb Group in a blended learning context as suggested in the product. This can be concluded from the exploration of supports for $\mathrm{Fb}$ Group as well as supporting factors for blended learning such as facilities, related skills and experiences on technology, and institutional policy. Facilities related to technological usage consist of classroom, personal and public facilities. Classroom facilities come in LCD projector and internet connections. After indicating whether they really need the related product or not, then the teachers gave suggestions on the relevant criteria for product development. 


\section{Product Development}

In this study, I planned to design a TG to use Facebook Group as an online medium in a blended Writing Course context. By making use of this guide, the tertiary teachers -who are supposed to be more familiar with social media, are introduced to the usage of Facebook Group as a learning tool and to the recent learning context with technology called blended learning. Not only presenting underlying theories and principles, this guide also gives adequate concerns on language contents and teaching procedure as well as practical alternatives or models. Here I preferred Facebook Group to any online platform such as Edmodo since their active users are much higher than edmodo's. The familiarity of any social media is definitely influencing the effectiveness of their notifications. The more frequent the users access any social medium, the more effective that social medium will be.

\section{Tryout}

As mentioned before, tryout was held soon after the expert validated the developed products. The procedure or learning model as suggested in teachers' guide (TG) was tested in several tryouts. Tryout 1 was testing the procedure before having the trial as recommeded by the TG. Tryout (TO) 1 resulted in $22 \%$ for the level of feasibility on procedure. The FGD 1 which followed the TO 1 recommended the continuation of the tryout involving the same group of students with the adjustment on learning procedure into RPC $1 \mathrm{hr}$. In the Tryout 2, the level of feasibility on procedure improved into $75 \%$ and it was recommended to do the Tryout 3 involving another group with the adjustment on learning procedure into RPC $1 \mathrm{hr}+$.The level of feasibility sharply increased into $97 \%$ in Tryout 3. The mistake occured in Tryout 3 was only from personal motivation.

Based on the results of the tryouts as well as their significant progress, the field expert of Writing Course recommended that the tryout could be terminated accordingly. He thought that the teachers' guide was feasible enough to be a guideline in the real situation. Besides, all participants of FGD 3 also claimed the same thing about the teachers' guide suggesting online learning in a blended Writing Course context. Having them consulted to the first thesis supervisor, he suggested that the tryout should be continued to involve two more teachers at least in order to increase the credibility of the practical justification. The two additional tryouts were 
then conducted simultaneously during the extended period of tryout resulted in $94 \%$ and $92 \%$ of the feasibility level on the procedure.

\section{Final draft}

In the first three tryouts, there are several differences found before and after the tryouts. The first difference is about the method's name. It is called as "Reading, Posting and Commenting (RPC)"before the tryouts and later on it is added with "Checking" to be "Reading, Posting, Checking and Commenting (RP2C)"'. Before the tryout, the time for posting and commenting is 24 hoursasynchronously, the tryouts lead to different direction where the time should be flexible. It is 1hour of synchronous 'prime time' plus additional times done asynchronously.Another difference is on the teacher's activity where teacher keeps on checking the students' works from posting until the learning has finished in one-hour-prime time. This differs from the previous procedure where teacher was not demanded to play an active role of checking the students' works.

In addition, based on the evaluation as well as the recommendations from the executing teachers of the two additional tryouts, I then made a list of revisions to be executed to finally generate a final draft of the product. Besides the teacher's evaluation and recommendations, the researcher's notes on the tryouts were also considered for listing up several revisions.

\section{CONCLUSIONS}

As the conclusion, concerning the existence of TG in IAIN Surakarta, I found only one TG used for Writing Course in IAIN Surakarta. The only TG used was about graphic organizers entitled Teacher's Big Book of Graphic Organizers by Katherine S. McKnight. This TG was employed partially by Teacher F to support his Writing Course, especially in drafting phase. In total, there were 39 materials identified as language learning materials. The most commonly used materials (35 materials) were called as general materials for Writing Course including textbooks/workbooks, supplements to coursebooks, etc. The rest three materials were merely designed for teachers but could not be identified as teachers' guide, such as methodology book, assessment book, etc. From the evaluation of the teachers' guide, I found that the book is not 
specifically designed for teaching language but teaching in general. It brings about consequences that teachers should give more effort on its adaptation or exploration for language teaching.

For the second question concerning teachers' needs of the proposed product, I found that it was significantly different from the investigation of the first question. Even there was only one teachers' guide available; it does not mean that the teachers did not need such product. Based on questionnaire and interview, I got a result that nine teachers considered teachers' guide (related to teaching with technology) as their needs and one teacher stated his uncertainty. Besides, they also supported and expected to have a product to use Facebook Group as the learning media and blended learning as the learning context. In total, there were ten criteria advocated by the teachers for product development.

Lastly, in developing the product, I involved two experts with their own different jobs. The first expert, also called as material development expert, assessed and validated the product before the field tryout while the second expert gave his judgment based on the field tryout. After being validated, I tried out the product in the field to test the feasibility of the learning procedure as suggested in the product. Evaluation of the tryout was facilitated through focus group discussion (FGD) which was conducted after the tryout. Along with the teacher, I also determined several criteria to evaluate the tested procedure so that the level of feasibility could be assessed easily. Through five times of tryout conducted, the level of feasibility on the procedure had improved significantly to $97 \%, 94 \%$ and $92 \%$ in the last three tryouts delivered by three different teachers. The tryout was terminated as suggested by the field expert and after the supervisor stated the credible justification had been reached. Finally, after being revised as recommended, the teachers' guide was ready-to-use in a blended writing course context.

\section{Implications and suggestions}

As it is concluded, there was only one teachers' guide available for Writing Course in IAIN Surakarta. The rests were 38 materials for language learning which could not be categorized as teachers' guide. However, this does not mean that teachers' guides were no more important for teachers. Instead, nine teachers (out of ten) thought that they needed teachers' guide for using new media or technology. Thus, they would need the product if they thought that it was really helpful for them. Otherwise, they would never be interested to try the new product 
offered. In research-based materials development, this means a lot that any researchers should think again and again on the product they plan to develop, whether the product is really needed or not.

Principally, teachers' guide is produced to aid teachers in numerous ways but not to dictate a rigid predetermined method by which the language shall be taught and learned. However, the teachers' guide developed in this study suggests the implementation of a procedure only. To have more alternatives on the procedure, other researchers are encouraged to develop different procedures and follow the similar processes of research-based development. In addition to the procedure suggested in this teachers' guide, there is a potential implication in its implementation in which the teacher's effort and role can be reduced periodically following the students' routines on this online learning.

This kind of research-based development is different from other educational research methods. The basic or applied research does not yield certain ready-to-use product. They may involve some development of educational products but only to the point where they can be used to test the hypotheses. By conducting this research and development (R\&D), the proposed product was systematically researched and tried out to be a product which is ready for operational use. However, since this study was not conducted to fulfill all the developmental stages as suggested, there is a great potential for other researchers to continue this study. On the other hand, the product produced from this R\&D can be simply employed for having educational research in other methods such as classroom action research and experimental research.

\section{REFERENCES}

Arbaugh, J.B., Desai, A. R. B., and Sridhar B.S. 2010. A Review of Research on Online and Blended Learning in the Management Discipline: 1994-2009. Organization Management Journal, 7.

Borg, W. R. and Gall, M. D. 1983. Educational Research: An Introduction. Fourth Edition. Boston: Pearson.

Brown, H. D. 2001. Teaching by Principles: An Interactive Approach to Language Pedagogy. Second Edition. New York: Addison Wesley Longman, Inc.

Creswell, J. W. 2009. Research Design: Qualitative, Quantitative, and Mixed Methods Approaches. Third Edition. California: Sage Publications, Inc.

Cunningsworth, A. 1995. Choosing Your Coursebook. Oxford: Macmillan Education. 
Cunningsworth, A., and Kusel, P. 1991. Evaluating teachers' guides.ELT Journal Volume 45/2.

Daniels, H. L. and Moore, D. M. 2000. Interaction of cognitive style and learner control in a hypermedia environment.International Journal of Instructional Media,27(4): 1-15.

Dey, I. 1993. Qualitative Data Analysis: A User-Friendly Guide for Social Scientists. New York: Routledge.

Fontana, A. 2009. The Multichronic Classroom: Creating an Engaging Environment for All Students in FATE vol. 30.

Gall, M.D., Joyce P.G. and W.R. Borg. 2003. Educational Research. Boston: Pearson Education, Inc.

Garrison, D.R., and N. Vaughan. 2008. Blended learning in higher education. San Francisco: Jossey-Bass.

Graham, C.R. 2006. Blended learning systems: Definition, current trends, and future directions. In Bonk, C.J. \& Graham, C.R. (eds.). Handbook of Blended Learning: Global Perspectives, Local Designs, pp. 3-21. San Fransisco: Pleiffer Publishing.

Greenhow, C., Robelia, B. and Hughes J. E. 2009. Web 2.0 and Classroom Research: What Path Should We Take Now? in Educational Researcher (38: 246). Aera and SAGE.

Huang R., Ding M. and Haisen Z. 2008. "Toward a Design Theory of Blended Learning Curriculum" in Fong J., Kwan R., and Wang F.L. (ed.). Hybrid Learning and Education (Proceedings). 66-78. Berlin: Springer.

King, C and McSporran, M. 2005. Blended Is Better: Choosing Educational Delivery Methods. Retrieved November 22, 2012 from http://goo.gl/DBHNKF.

Lincoln, Y. S. \& Guba E.G. 1985. Naturalistic inquiry. California: SAGE Publications, Inc.

McKnight, K. S. 2010. The Teacher's Big Book of Graphic Organizers. San Fransisco: JosseyBass.

Miles, M.B. and A.M. Huberman. 1992. Qualitative Data Analysis: A Sourcebook of New Methods. Beverly Hills, CA: Sage Publications.

Morgan, D. L. 1996. Focus Groups. Annual Review of Sociology, vol. 22, pp. 129-152.

Nunan, David. 1991. Language Teaching Methodology: A Textbook for Teachers. London: Prentice Hall.

Patton, M.Q. 1980.Qualitative Evaluation Methods.Beverly Hills. CA: Sage Publications.

Promnitz, L. and Hayashi. 2011. A Learning Success Story Using Facebook in SiSAL Journal Vol. 2, No. 4, 309-316.Sisaljournal.org.

Picciano, A. G. 2006. "Blended learning: Implications for growth and access".Journal of Asynchronous Learning Networks 10 (3): 85-91, 2006

The Education Foundation. 2013. Facebook Guide for Educators: A tool for teaching and learning. London: The Education Foundation.

Tomlinson, B. (2012). Materials development for language learning and teaching.Lang. Teach., 45.2, 143-179.

Tri D., Made Y.S. and Boedhi O. 2007. E-Learning Pada Pendidikan Jarak Jauh: Konsep Yang Mengubah Metode Pembelajaran di Perguruan Tinggi di Indonesia. Jurnal Pendidikan Terbuka dan Jarak Jauh, Volume 8, Nomor 2. 
Wilson, V. 1997. Focus Groups: A Useful Qualitative Method for Educational Research? British Educational Research Journal, vol. 23, no. 2, pp. 209-224.

Zemach, D. E. and Islam, C. 2005. Paragraph Writing: From Sentence to Paragraph, Teacher's Guide. Oxford: Macmillan Education.

\section{Cited Regulations from the Government of Indonesia}

Peraturan Pemerintah Republik Indonesia Nomor 17 Tahun 2010 Tentang Pengelolaan dan Penyelenggaraan Pendidikan

Keputusan Menteri Pendidikan Nasional Republik Indonesia Nomor 232/U/2000 Tentang Pedoman Penyusunan Kurikulum Pendidikan Tinggi dan Penilaian Hasil Belajar Mahasiswa. 